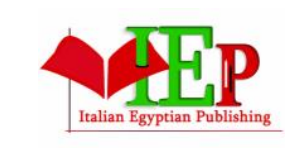

ISSN: $2735-4342$

\section{INTERNATIONAL JOURNAL OF \\ MULTIDISCIPLINARY STUDIES IN ART AND \\ TECHNOLOGY}

VOLUME 4, ISSUE 1, 2021, 159-173.

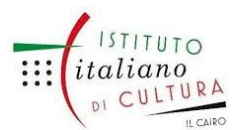

www.egyptfuture.org/ojs/

\title{
Employing Embroidery and Digital Printing Skills in the Production of Contemporary Artistic Paintings Inspired by Heritage
}

Marwa Mahmoud Abdel Hamid Issa, Ph.D.

Lecturer - Faculty of Arts and Design, Fashion Design Department, Pharos University in Alexandria engineermarwasaad@gmail.com

Dhttps://orcid.org/0000-0001-9557-8822

Web of Science Researcher ID is AAC-1557-2021

\begin{abstract}
We currently live in the era of globalization, where advanced modern technology is widespread, which has negatively affected Arab values and legacies. This has resulted in the replacement of Arab doctrine with foreign ones, which do not match our Arab personality and values. For this reason, there is much emphasis on reviving our heritage and producing sophisticated and aesthetical works of art using this technology. From this starting point, the researcher found that it is possible to combine digital printing and manual embroidery skills, by directing students to produce artistic paintings inspired by designs from our heritage, as well as contemporary modern trends. This approach can introduce new techniques for application, some of which have been taught to students during their years in university, linking them to society, encouraging innovation and creativity, and taking advantage of the skills they have acquired during their undergraduate years. Manual embroidery and digital printing are among the most important methods for decorating clothes and furnishings with different materials and techniques. Thus, combining these two methods can be an important form of artistic expression. This study aims to guide third-year students in the Fashion Design Department, at the Faculty of Arts and Design, Pharos University in Alexandria, to employ their embroidery and printing skills in a new and innovative manner, with the purpose of producing pieces of art with a distinguished aspect to revive our heritage. The produced paintings were evaluated by art specialists and artists for their aesthetic, functional, and innovative aspects. Furthermore, questionnaire results of the jury were statistically analyzed. Statistically significant differences were found between the produced artworks in achieving the desired aesthetic, functional, and creative aspects, according to the opinions of the judging specialists and artists. Correlations were also found between the opinions of the jury regarding the produced artwork in their ability to combine between the skills of manual embroidery and digital printing, to revive heritage and also fit contemporary trends.
\end{abstract}




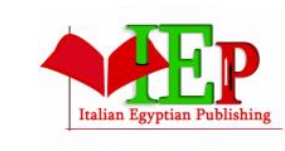

ISSN: $2735-4342$

\section{INTERNATIONAL JOURNAL OF \\ MULTIDISCIPLINARY STUDIES IN ART AND \\ TECHNOLOGY}

VOLUME 4, ISSUE 1, 2021, 159- 173.

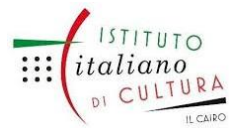

www.egyptfuture.org/ojs/

Keywords: Heritage Revival - Manual Embroidery - Digital Printing - Art Paintings - Contemporary Trend.

\section{Introduction:}

University education plays an important role in the development of the skills and personality of undergraduates and prepares them to join the workforce, by supplying them with opportunities to gain knowledge and apply acquired skills. Thus, getting students' projects to participate in research and conventions contributes to giving them direction and to consolidating their skills as graduates. This helps them better serve their community. On the other hand, it is necessary to revive our heritage, as the development of advanced, modern technologies around us has had a negative effect on the Arab culture. Thus, education can play a vital role in reviving this heritage and can direct students to develop projects and produce paintings to conserve it.

Embroidery and printing are among the main curricula being taught in the Fashion Design Department at Pharos University in Alexandria. These curricula include acquiring the necessary skills in manual and automatic embroidery and manual and digital printing, using different methods. This leads to different skills and techniques to embellish textile and to devise different designs. These skills also allow students to cope with the requirements of the employment market and to become more competitive, when applying for job opportunities in factories and companies.

Thus, the researcher has seen the importance of directing students to apply their skills in printing and manual embroidery to produce paintings, for the purpose of reviving our heritage and following contemporary trends. This, in turn, complies with workplace and work requirements and links higher education with projects serving the community, which encourages creativity and increases knowledge of Arab customs and practices and heritage, as well as complies with modern technology.

\section{Problem Statement:}

The time we currently live in is characterized by constant change. Thus, teaching methods and systems must accommodate this change to be able to serve and develop the community (1). On a different note, embroidery has become one of the most important methods used to decorate textiles, as it adds beauty and delicacy to fabrics. It is used to decorate and embellish clothing and textiles used in furnishings. As such, it is considered a type of artistic expression (2). Embroidery is also considered one of the methods used to encourage students to establish small-scale projects serving their community and overcoming the problem 


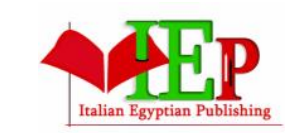

ISSN: $2735-4342$

\section{INTERNATIONAL JOURNAL OF \\ MULTIDISCIPLINARY STUDIES IN ART AND \\ TECHNOLOGY}

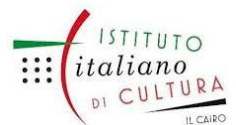

www.egyptfuture.org/ojs/

of unemployment (3). Manual embroidery has many beautiful formations and can employ natural and synthetic materials and threads to enrich artistic work (4). Embroidery is considered one of the oldest methods of art expression, whether using one or several colors, a single stich, several stitches, or more complex ones, as they all add beauty to any piece. On the other hand, printing is one of the simplest and cheapest methods commonly used to produce a multi-colored piece of clothing, as opposed to using different types of dyed thread (5). Embroidery and printing can be combined to enrich designed ornamentation, to develop and consolidate aesthetic values, and to conserve our identity (6). Heritage is human knowledge that people gather and employ, as it reflects identity and a population's unique cultural heritage (7).

From the above overview of the literature, the problem statement can be summarized as follows:

1. The possibility of combining printing and embroidery to produce modern paintings

2. The opinion of those specializing in the field, as well as artists in the produced paintings from an aesthetic, functional, and creative point of view

3. The possibility of making use and employing students' skills to revive heritage and follow modern trends

\section{Purpose of the Research}

1. Employing manual embroidery and digital printing skills to produce paintings

2. Linking scientific research with academic education and community service

3. Employing different types of material and keeping up with modern trends in creating works of art with a special flavor

4. Directing third-year students in fashion and design and helping them benefit from what they have learned and linking it to practice

5. Encouraging heritage revival through manual and digital artistic methods to comply with modern trends

\section{Importance of the Research}

- Reviving heritage by combining manual embroidery and digital printing to produce artistic paintings with a special modern flavor 


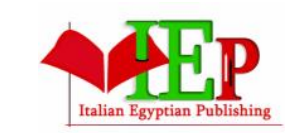

ISSN: $2735-4342$

\section{INTERNATIONAL JOURNAL OF \\ MULTIDISCIPLINARY STUDIES IN ART AND \\ TECHNOLOGY}

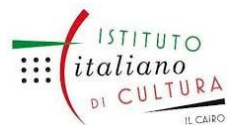

www.egyptfuture.org/ojs/

- Helping third-year students gain the skills and knowledge to improve their academic performance and helping them feel positive about their experience in university, in general and in the Fashion Design Department at Pharos University in Alexandria, in specific

- Adding variety to the methods of combining materials and decorating textile to achieve the functional, aesthetic, and creative aspects

\section{Hypotheses of the Research}

1. There are statistically significant differences between paintings in achieving the aesthetic aspect, according to the opinions of art specialists and artists

2. There are statistically significant differences between paintings in achieving the functional aspect, according to the opinions of art specialists and artists

3. There are statistically significant differences between paintings in achieving the creative aspect, according to the opinions of art specialists and artists

\section{Research Methodology}

Research methodologies employed in this is study are the experimental and descriptive methodologies.

\section{Tools of the Research}

A questionnaire to evaluate the paintings by art specialists and artists.

\section{Limitations of the Research}

The research had the following limitations:

- Spatial limitation: Pharos University in Alexandria, Faculty of Arts and Design

- Time limitation: Fall term of the 2020-2021 academic year

- Human limitation: Third-year students of the Fashion Design Department

\section{Terms Used in the Research}

1. Manual embroidery is a decorative art, using different types of materials on textile. For the purpose of this research, various types of threads and some accessories, including beading, were used. The Arabic word tatriz, meaning embroidery comes from the Persian word tarazidan. 


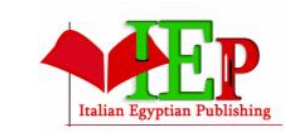

ISSN: $2735-4342$

\section{INTERNATIONAL JOURNAL OF \\ MULTIDISCIPLINARY STUDIES IN ART AND \\ TECHNOLOGY}

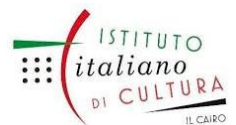

www.egyptfuture.org/ojs/

2. Digital printing is one of the fastest methods of printing currently available, as it removes several stages from the printing process and achieves high quality and durability of colors even after washing.

3. Heritage: In the Arabic language, the word torath (heritage) comes from warath, one of the Arabic words meaning what a person inherits, whether moral or materialistic. Egyptian heritage has a special flavor, as it has been affected by various civilizations and cultures over the years.

\section{Theoretical Framework:}

Embroidery is an elective subject taught to third-year students in the Fashion Design Department at the Faculty of Arts and Design, Pharos University in Alexandria. The researcher has taught the curriculum educating students about embroidery, which includes the use of several types of threads and materials, the study of the various types of basic and aesthetic stitches, and types of decoration using accessories and a combination of materials. The curriculum also addresses the history of embroidery during the different ages and its development, as well as the application of the material taught in the production of paintings from the Arab heritage to follow modern trends and showing them to specialists in the field, as well as artists to evaluate them from an aesthetic, functional, and creative point of view. Types of embroidery vary between those using satin tape, beading, and threads, in addition to the use of etamine, canvas, and crochet. The research has focused on unifying the type of embroidery employed, by using different types of thread or accessories, need be.

Practical Framework (Employing the skills of digital printing and manual embroidery to produce modern artistic paintings):

Third-year students in the Fashion Design Department at Pharos University in Alexandria designed and produced several artistic paintings. The best nine modern paintings, inspired by heritage characterized by their aesthetic, functional, and creative aspects were chosen.

\section{\begin{tabular}{|l|l} 
Serial & Description of the Artwork
\end{tabular}}

Photo of the Artwork 
INTERNATIONAL JOURNAL OF

MULTIDISCIPLINARY STUDIES IN ART AND

TECHNOLOGY

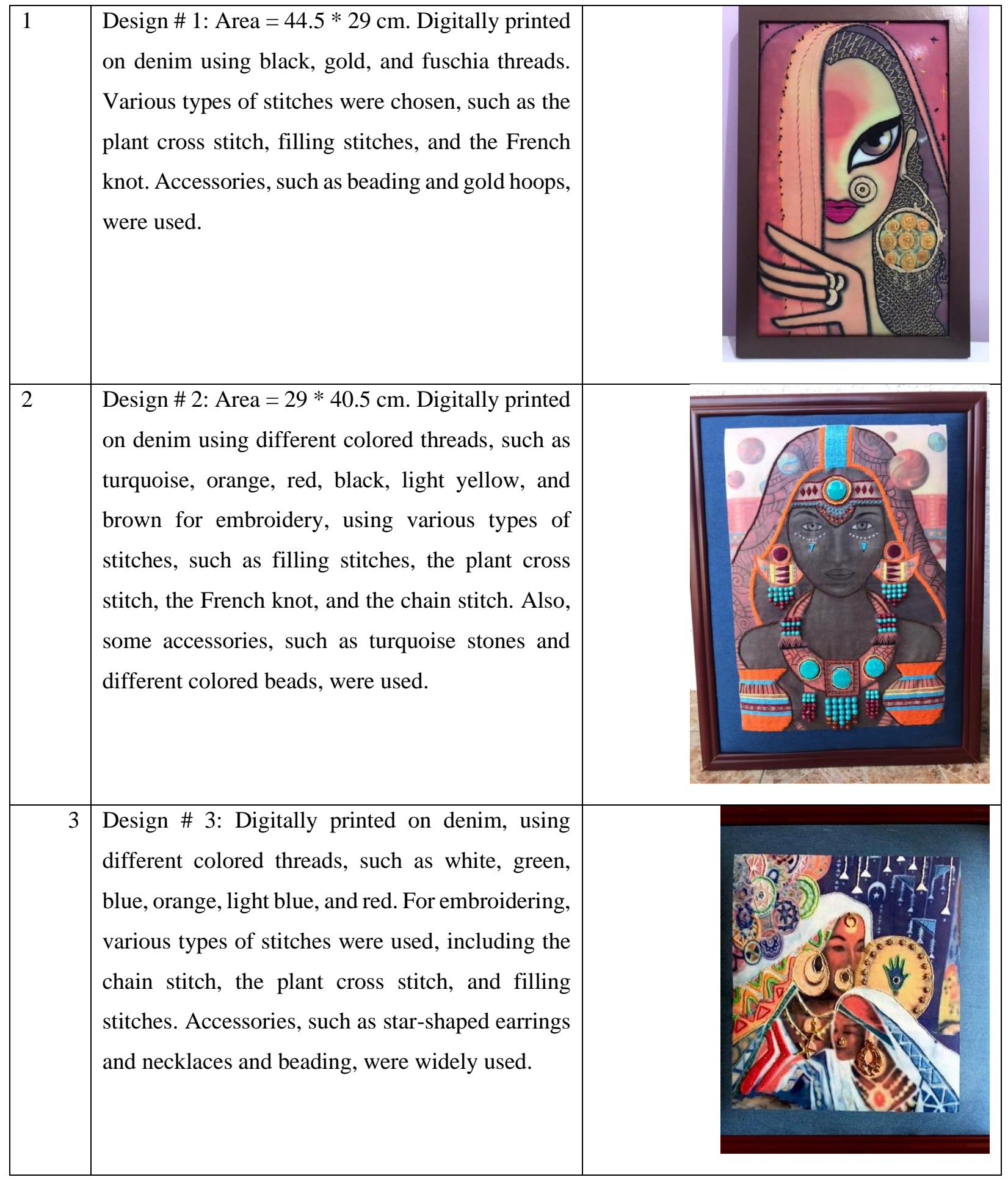


INTERNATIONAL JOURNAL OF

MULTIDISCIPLINARY STUDIES IN ART AND

TECHNOLOGY

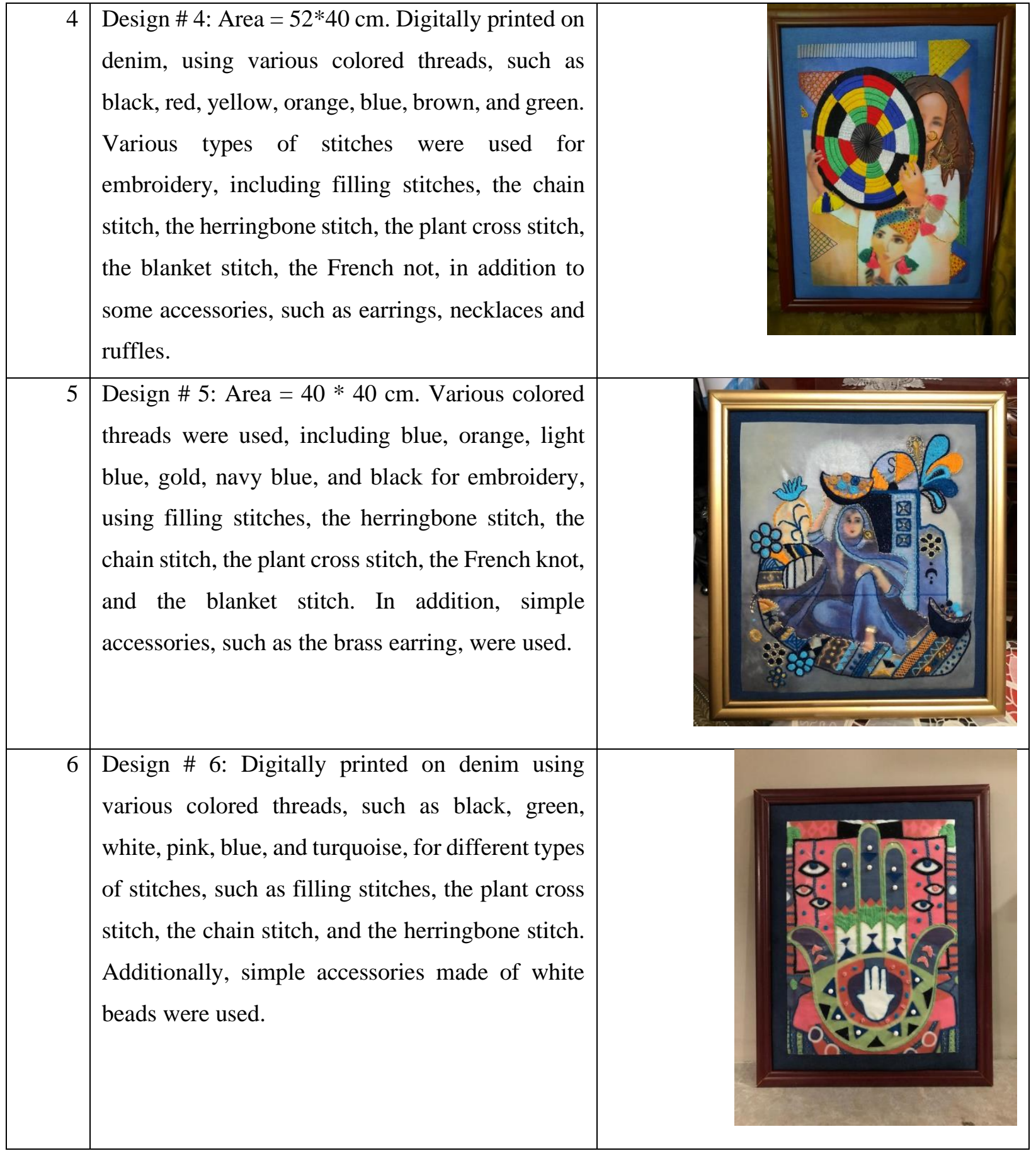


INTERNATIONAL JOURNAL OF

MULTIDISCIPLINARY STUDIES IN ART AND

TECHNOLOGY

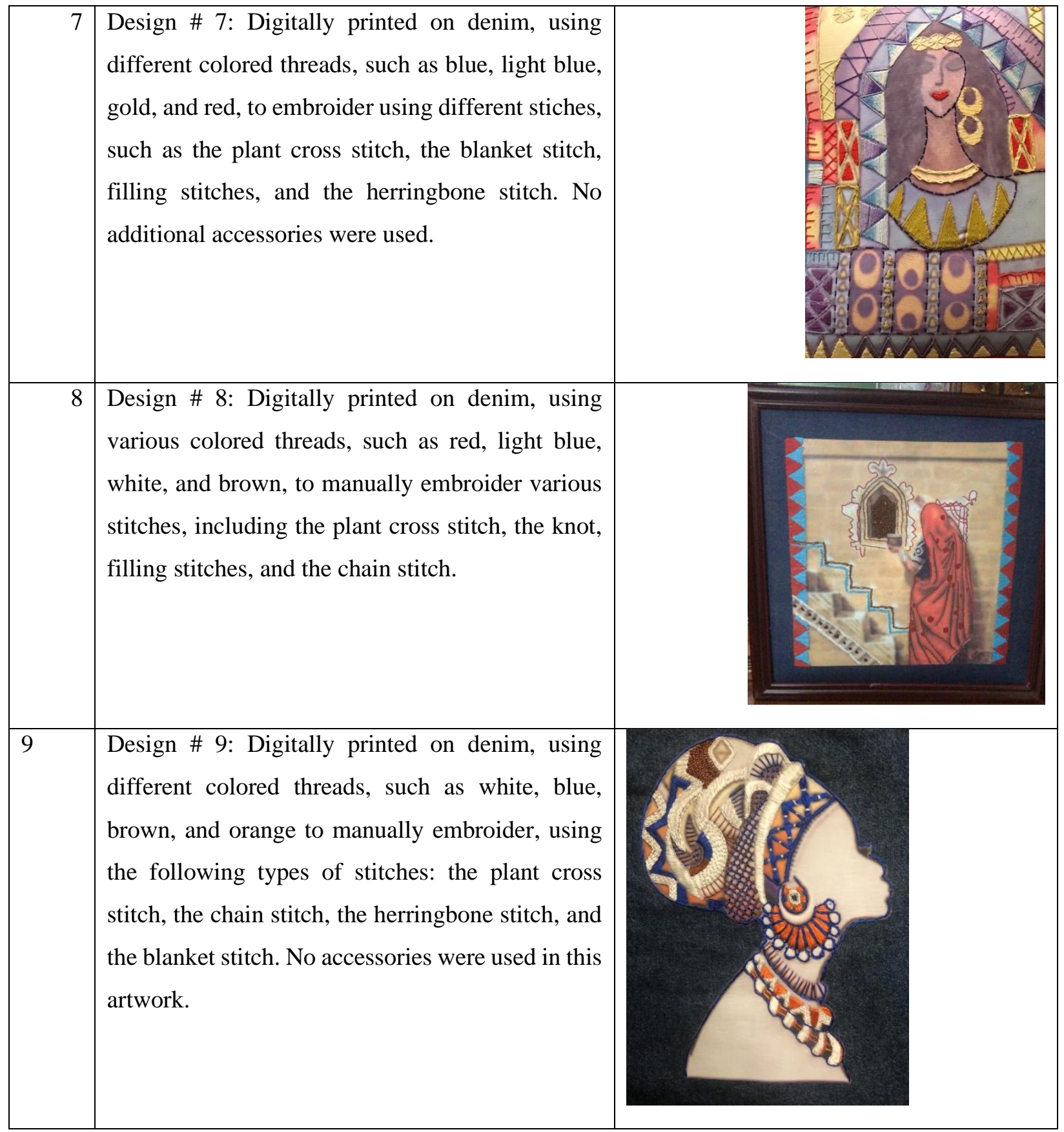

Artworks were evaluated by art specialists and artists, according to the questionnaire in Appendix (1).

\section{Statistical Analysis}

A questionnaire to evaluate the paintings by art specialists and artists was prepared to show the degree they were able to achieve the aesthetic, functional, and creative aspects. Then, mean scores and percentages of 


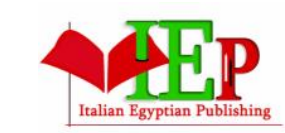

ISSN: $2735-4342$
INTERNATIONAL JOURNAL OF

MULTIDISCIPLINARY STUDIES IN ART AND

TECHNOLOGY

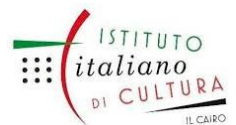

www.egyptfuture.org/ojs/

the results of the evaluation of the paintings, according to the items of the questionnaire, to check the ability of the paintings to revive heritage and follow modern trends, were calculated. The results of the questionnaire were analyzed using Microsoft Excel. After calculating mean scores and percentages and conducting the ANOVA test, research results were reached to prove the hypotheses of the study.

\section{Results and Discussion:}

The first hypothesis suggested the presence of statistical significance between paintings in achieving the aesthetic aspect, according to the opinions of art specialists and artists. To test this hypothesis, the mean and percentages of the scores of evaluation were calculated, as per Table 1. Additionally, the ANOVA test for variance analysis of the average scores was performed. It showed the presence of statistical significances and significant differences between paintings, where the peak significance was found to be 0.0088 (less than 0.05), as seen in Table 2.

Table 1: Arithmetic means and percentages of the items ensuring the achievement of the aesthetic aspect in the paintings.

\begin{tabular}{|c|c|c|c|c|c|}
\hline First Aspect & $\begin{array}{c}\text { Statistical } \\
\text { Indicators }\end{array}$ & Means & Percentages & $\begin{array}{c}\text { Total } \\
\text { Arithmetic } \\
\text { Mean }\end{array}$ & $\begin{array}{c}\text { Total } \\
\text { Percentage }\end{array}$ \\
\hline $\begin{array}{l}\text { Achieving the } \\
\text { Aesthetic }\end{array}$ & $\begin{array}{l}\text { Techniques } \\
\text { used }\end{array}$ & 4.55 & 90.92 & \multirow{4}{*}{4.45} & \multirow{4}{*}{89} \\
\hline \multirow[t]{3}{*}{ Aspect } & $\begin{array}{l}\text { Precision of } \\
\text { application }\end{array}$ & 4.52 & 90.34 & & \\
\hline & $\begin{array}{l}\text { Color } \\
\text { coordination }\end{array}$ & 4.35 & 87.04 & & \\
\hline & $\begin{array}{l}\text { Suitability of } \\
\text { materials }\end{array}$ & 4.38 & 87.68 & & \\
\hline
\end{tabular}

Table 2: Analysis of the variances of the mean scores in achieving the aesthetic aspect in paintings.

\begin{tabular}{|c|c|c|c|c|c|c|}
\hline $\begin{array}{c}\text { Aesthetic } \\
\text { Aspect }\end{array}$ & $\begin{array}{c}\text { Total } \\
\text { Squares }\end{array}$ & $\begin{array}{c}\text { Degree of } \\
\text { Freedom }\end{array}$ & $\begin{array}{c}\text { Mean } \\
\text { Squares }\end{array}$ & $F$-value & Significance & $\begin{array}{c}\text { Tabulated } \\
F \text {-value }\end{array}$ \\
\hline
\end{tabular}


INTERNATIONAL JOURNAL OF

MULTIDISCIPLINARY STUDIES IN ART AND

TECHNOLOGY

\begin{tabular}{|c|c|c|c|c|c|c|}
\hline $\begin{array}{c}\text { Between } \\
\text { Groups }\end{array}$ & 0.9497 & 8 & 0.118 & & & \\
\cline { 1 - 3 } $\begin{array}{c}\text { Within } \\
\text { Groups }\end{array}$ & 0.961 & 27 & 0.036 & 3.34 & 0.0088 & 2.31 \\
\cline { 1 - 4 } Total & 1.9108 & 35 & & & \\
\hline
\end{tabular}

The second hypothesis stated the presence of a statistical significance between paintings in achieving the functional aspect, according to the opinions of art specialists and artists. To test this hypothesis, the means and percentages of the evaluation scores were calculated, as seen in Table 3. Additionally, the ANOVA test of variance analysis of mean scores was calculated. Statistical significances and significant differences were found between paintings, as the peak significance was 0.0059 (less than 0.05), as seen in Table 4 .

Table 3: Arithmetic means and percentages of the items ensuring the achievement of the functional aspect in paintings.

\begin{tabular}{|c|c|c|c|c|c|}
\hline $\begin{array}{l}\text { Second } \\
\text { Aspect }\end{array}$ & $\begin{array}{c}\text { Statistical } \\
\text { Indicators } \\
\text { Items }\end{array}$ & Means & Percentages & $\begin{array}{c}\text { Total } \\
\text { Arithmetic } \\
\text { Mean }\end{array}$ & $\begin{array}{c}\text { Total } \\
\text { Percentage }\end{array}$ \\
\hline \multirow[t]{3}{*}{$\begin{array}{l}\text { Achieving the } \\
\text { Functional } \\
\text { Aspect }\end{array}$} & $\begin{array}{l}\text { Harmony } \\
\text { between } \\
\text { printing and } \\
\text { embroidery } \\
\text { techniques }\end{array}$ & 4.36 & 87.24 & \multirow{3}{*}{4.38} & \multirow{3}{*}{87.63} \\
\hline & $\begin{array}{l}\text { Realizing the } \\
\text { beneficial } \\
\text { aspect }\end{array}$ & 4.3 & 86.09 & & \\
\hline & $\begin{array}{l}\text { The degree of } \\
\text { accordance } \\
\text { between the } \\
\text { design and } \\
\text { heritage }\end{array}$ & 4.48 & 89.52 & & \\
\hline
\end{tabular}


INTERNATIONAL JOURNAL OF

MULTIDISCIPLINARY STUDIES IN ART AND

TECHNOLOGY

\begin{tabular}{|l|l|l|l|l|l|}
\hline & $\begin{array}{l}\text { Possibility of } \\
\text { marketing }\end{array}$ & 4.38 & 87.67 & & \\
\hline
\end{tabular}

Table 4: Analysis of the variances of the mean scores in achieving the functional aspect in the paintings.

\begin{tabular}{|c|c|c|c|c|c|c|}
\hline $\begin{array}{c}\text { Functional } \\
\text { Aspect }\end{array}$ & $\begin{array}{c}\text { Total } \\
\text { Squares }\end{array}$ & $\begin{array}{c}\text { Degree of } \\
\text { Freedom }\end{array}$ & $\begin{array}{c}\text { Mean } \\
\text { Squares }\end{array}$ & F-value & Significance & $\begin{array}{c}\text { Tabulated } \\
\text { F-value }\end{array}$ \\
\cline { 1 - 4 } $\begin{array}{c}\text { Between } \\
\text { Groups }\end{array}$ & 0.75 & 8 & 0.094 & & & \\
\cline { 1 - 4 } $\begin{array}{c}\text { Within } \\
\text { Groups }\end{array}$ & 0.71 & 27 & 0.026 & 3.58 & 0.0059 & 2.305 \\
\cline { 1 - 4 } Total & 1.46 & 35 & & & \\
\hline
\end{tabular}

The third hypothesis stated the presence of a statistical significance between paintings in achieving the creative aspect, according to the opinions of art specialists and artists. To test this hypothesis, the means and percentages of the evaluation scores were calculated, as seen in Table 5. Additionally, the ANOVA test of the variance analysis of mean scores was calculated. Statistical significances and significant differences were found between paintings, as the peak significance was 0.01 (less than 0.05 ), as seen in Table 6 .

Table 5: Arithmetic means and percentages of the items ensuring the achievement of the creative aspect in paintings.

\begin{tabular}{|c|c|c|c|c|c|}
\hline Third Aspect & $\begin{array}{c}\text { Statistical } \\
\text { Indicators } \\
\text { Items }\end{array}$ & Means & Percentages & $\begin{array}{c}\text { Total } \\
\text { Arithmetic } \\
\text { Mean }\end{array}$ & $\begin{array}{c}\text { Total } \\
\text { Percentage }\end{array}$ \\
\hline \multirow{2}{*}{$\begin{array}{l}\text { Achieving the } \\
\text { Creative } \\
\text { Aspect }\end{array}$} & $\begin{array}{l}\text { Modernity of } \\
\text { the product }\end{array}$ & 4.22 & 84.44 & \multirow[b]{2}{*}{4.25} & \multirow[b]{2}{*}{85.05} \\
\hline & $\begin{array}{l}\text { Combining } \\
\text { between } \\
\text { materials used } \\
\text { in printing and }\end{array}$ & 4.37 & 87.36 & & \\
\hline
\end{tabular}


INTERNATIONAL JOURNAL OF

MULTIDISCIPLINARY STUDIES IN ART AND

TECHNOLOGY

\begin{tabular}{|l|l|l|l|l|l|}
\hline & $\begin{array}{l}\text { those used in } \\
\text { embroidery }\end{array}$ & & \multirow{2}{*}{ (4.36 } & & \\
\cline { 2 - 5 } & $\begin{array}{l}\text { Achieving } \\
\text { authenticity } \\
\text { and uniqueness }\end{array}$ & 4.17 & 83.36 & \\
\hline
\end{tabular}

Table 6: Analysis of the variances of the mean scores in achieving the creative aspect in paintings.

\begin{tabular}{|c|c|c|c|c|c|c|}
\hline $\begin{array}{c}\text { Aesthetic } \\
\text { Aspect }\end{array}$ & $\begin{array}{c}\text { Total } \\
\text { Squares }\end{array}$ & $\begin{array}{l}\text { Degree of } \\
\text { Freedom }\end{array}$ & $\begin{array}{c}\text { Mean } \\
\text { Squares }\end{array}$ & $F$-value & Significance & $\begin{array}{c}\text { Tabulated } \\
F \text {-value }\end{array}$ \\
\hline $\begin{array}{c}\text { Between } \\
\text { Groups }\end{array}$ & 0.864 & 8 & 0.108 & \multirow{3}{*}{2.35} & \multirow{3}{*}{0.01} & \multirow{3}{*}{2.51} \\
\hline $\begin{array}{l}\text { Within } \\
\text { Groups }\end{array}$ & 0.955 & 18 & 0.053 & & & \\
\hline Total & 1.819 & 26 & & & & \\
\hline
\end{tabular}

\section{Recommendations of the Research:}

1. Each of the art specialists and artists verified that the aesthetic, functional, and creative aspects were achieved in the produced paintings, which proves the role of the Fashion Design Department at Pharos University in Alexandria in serving the community.

2. The researcher recommends setting up exhibits for students and using their work to participate in scientific research, so as to encourage them and raise their spirits, as well as to link between educational curricula and the requirements of the marketplace.

3. The researcher recommends holding training courses and workshops to improve and reinforce students' skills and their participation in community service and to link them to factories and companies and raise the skill sets of graduates. 
INTERNATIONAL JOURNAL OF

MULTIDISCIPLINARY STUDIES IN ART AND

TECHNOLOGY

ISSN: 2735-4342

VOLUME 4, ISSUE 1, 2021, $159-173$.

www.egyptfuture.org/ojs/

\section{Employing Embroidery and Digital Printing Skills in the Production of Contemporary Artistic Paintings Inspired by Heritage}

Appendix 1 - Evaluation form for modern artistic paintings inspired by heritage, to be filled by art specialists and artists.

\begin{tabular}{|c|c|c|c|c|c|c|c|c|}
\hline Design & $\begin{array}{c}\text { Aspects } \\
\text { for } \\
\text { Evaluation }\end{array}$ & Evaluation Items & 1 & 2 & 3 & 4 & 5 & Comments \\
\hline \multirow[t]{3}{*}{$\begin{array}{l}\text { From } 1 \\
\text { to } 9\end{array}$} & Aesthetic & $\begin{array}{ll}\text { - } & \text { Techniques used } \\
\text { - } & \text { Precision of application } \\
\text { - } & \text { Color coordination } \\
\text { - } & \text { Suitability of materials }\end{array}$ & & & & & & \\
\hline & Functional & 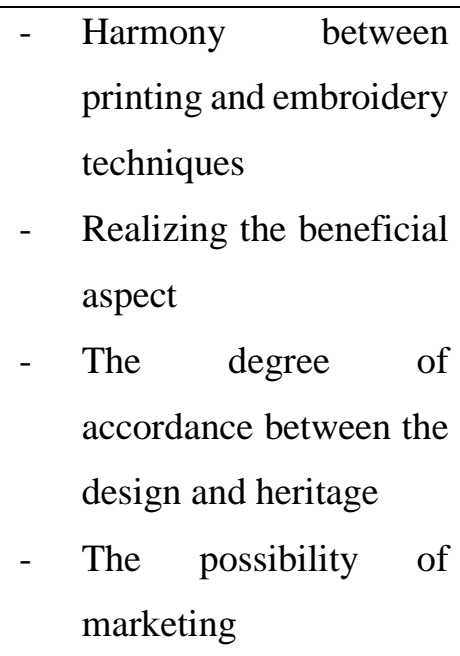 & & & & & & \\
\hline & Creative & 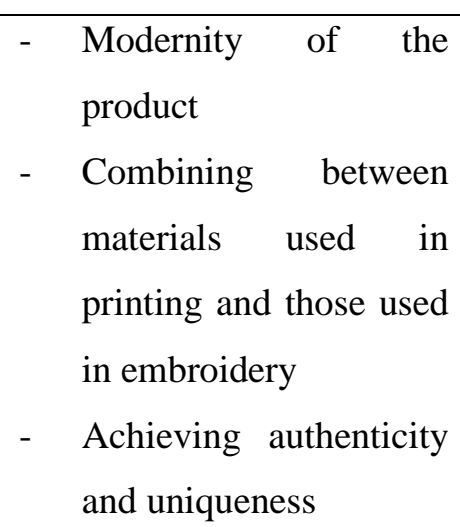 & & & & & & \\
\hline
\end{tabular}




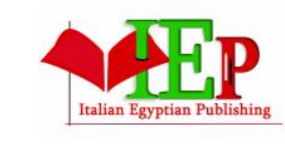

ISSN: $2735-4342$

\section{INTERNATIONAL JOURNAL OF \\ MULTIDISCIPLINARY STUDIES IN ART AND \\ TECHNOLOGY}

VOLUME 4, ISSUE 1, 2021, 159-173.

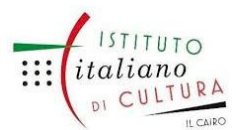

www.egyptfuture.org/ojs/

Note: Scores from 1 to 5 represent the following:

1: Poor

2: Acceptable

3: Good

4: Very good

5: Excellent

The questionnaire was presented to artists and art specialists to determine if the evaluation items were achieved in the paintings. 


\section{INTERNATIONAL JOURNAL OF MULTIDISCIPLINARY STUDIES IN ART AND TECHNOLOGY}

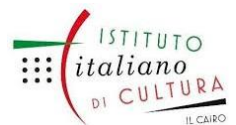

www.egyptfuture.org/ojs/

\section{References}

1. El Zeftawi, H. N., El Garhi, S. A. H. (2006). The efficiency of an educational video program in acquiring the skills for certain embroidery techniques, Journal of Sciences and Arts-Studies and Research, 18(4): 133-153.

2. Al Gohary, R. A. M. M. (2016). The efficiency of a training program in enriching furnishings by using embroidery techniques to raise the economic level of Egyptian families. Journal of Specific Education Research, (43): 2-50.

3. Mohamed, F. N. K. (2016). Directing students to employ educational curricula in establishing small-scale projects: The example of the curriculum of embroidery and crochet. Third Scientific and First International Conference: Developing Specific Education in Light of Environmental Studies, (3): 308-341.

4. Farag, A. S. (2018). Formation possibilities of combining natural and synthetic materials in manual embroidery to enrich artistic products, Scientific Journal of Educational and Specific Studies and Research, (4): 1-18.

5. Metwally, R. A. M. (2010). Printing and embroidery on etamine as an introduction to decorate clothing accessories for the female university student, Journal of Specific Education Research, (16): 310-350.

6. Zalat, A. E., Al Gohary, R. A. M. M., El Adawi, N. H., Hafez, S. M. (2017). Benefiting from the techniques of printing and embroidery to enrich the folkloric decorations of children's clothing, Journal of Specific Education Research, (47): 423-478.

7. Kamel, M. S. (2015). A modern Egyptian trend inspired by Nubian heritage. International Design Journal, 5(4): 1645-1654.

8. Mohammed GHAZI, Rania, Shawky, AN EDUCATIONAL APPLICATION OF MOBILE PHONES TO IMPROVE THE EMBROIDERY SKILLS OF USING THE HOME SEWING MACHINES TECHNIQUES FOR THE STUDENTS, International Journal of Multidisciplinary Studies in Art and Technology, Vol.1, No.1, 2018, pp. 7-10.

Received: June 2021

Accepted: April 2021 